\title{
Beluga Vocalizations Decrease in Response to Vessel Traffic in the Mackenzie River Estuary
}

\author{
William D. Halliday, ${ }^{1,2,3}$ Kevin Scharffenberg, ${ }^{4,5}$ Shannon MacPhee, ${ }^{4}$ R. Casey Hilliard, ${ }^{6}$ Xavier Mouy, ${ }^{7,8}$ \\ Dustin Whalen, ${ }^{9}$ Lisa L. Loseto ${ }^{4,10}$ and Stephen J. Insley ${ }^{1,2}$
}

(Received 22 March 2019; accepted in revised form 26 July 2019)

\begin{abstract}
Vessel traffic negatively affects marine mammals by causing behavioural disturbance, acoustic masking, contamination (i.e., oil spills), and ship strikes. Few studies have examined the effects of vessels on marine mammals in the Arctic, but beluga whales appear to be especially sensitive to vessel traffic. We examine how the vocalizations of belugas are impacted by vessel traffic in the Tarium Niryutait Marine Protected Area in the Mackenzie River estuary of the western Canadian Arctic. Between one and four acoustic recorders were deployed between June and August each year between 2015 and 2018 near the only shipping channel at this site. We examined beluga vocalizations from acoustic recordings over four summers and assessed how the distance to the nearest vessel passing the acoustic recorder affected the number of vocalizations. Beluga vocalizations within the range of the acoustic recorder decreased significantly when vessels were within $5 \mathrm{~km}$ of the acoustic recorder. This result suggests either that belugas are avoiding the vessel or that they reduce their vocalization in response to vessel traffic. Future work is needed to assess exactly how belugas are reacting to vessel traffic in this area and what the long-term consequences of these reactions are. Management measures for reducing these impacts must be carefully considered, especially since these vessels are very restricted in where they can travel, and many of the vessels are necessary for the livelihoods of local communities.
\end{abstract}

Key words: behavioural disturbance; Delphinapterus leucas; shipping; underwater noise

RÉSUMÉ. La circulation maritime a des effets négatifs sur les mammifères marins, car elle entraîne des perturbations comportementales, masque leurs signaux acoustiques et engendre de la contamination (comme des déversements de pétrole) et des collisions. Bien que peu d'études aient examiné les effets des bateaux sur les mammifères marins de l'Arctique, les bélugas semblent particulièrement sensibles à la circulation maritime. Dans cet article, nous examinons en quoi les vocalisations des bélugas sont touchées par la circulation maritime dans la zone de protection marine de Tarium Niryutait faisant partie de l'estuaire du fleuve Mackenzie, dans l'ouest de l'Arctique canadien. Entre un et quatre enregistreurs acoustiques ont été déployés de juin à août de chaque année entre 2015 et 2018, à proximité du seul chenal de navigation de l'endroit. Nous avons examiné les vocalisations des bélugas prélevées à l'aide des enregistreurs acoustiques au cours de quatre étés, et évalué en quoi la distance du bateau passant le plus près de l'enregistreur acoustique avait un effet sur le nombre de vocalisations. Les vocalisations des bélugas dans la zone de l'enregistreur acoustique diminuaient considérablement lorsque les bateaux se trouvaient à moins de cinq kilomètres de l'enregistreur. Ce résultat suggère soit que les bélugas évitent les bateaux, soit qu'ils réduisent leurs vocalisations en réponse à la circulation maritime. Il y a lieu de pousser cette étude plus loin pour évaluer exactement comment les bélugas réagissent à la circulation des bateaux dans cette région, et quelles sont les conséquences à long terme de ces réactions. Il y a lieu aussi de considérer avec soin des mesures de gestion pour réduire ces incidences, surtout parce que les déplacements de ces bateaux sont assujettis à de nombreuses restrictions et parce que grand nombre des bateaux qui passent par là sont nécessaires à la subsistance des collectivités de la région.

Mots clés : perturbations comportementales; Delphinapterus leucas; navigation; bruit sous-marin

Traduit pour la revue Arctic par Nicole Giguère.

\footnotetext{
${ }^{1}$ Wildlife Conservation Society Canada, 169 Titanium Way, Whitehorse, Yukon Y1A 0E9, Canada

${ }^{2}$ Department of Biology, University of Victoria, 3800 Finnerty Road, Victoria, British Columbia V8P 5C2, Canada

${ }^{3}$ Corresponding author: whalliday@wcs.org

${ }^{4}$ Freshwater Institute, Fisheries and Oceans Canada, 501 University Crescent, Winnipeg, Manitoba R3T 2N6, Canada

${ }^{5}$ Department of Biological Sciences, University of Manitoba, 500 University Crescent, Winnipeg, Manitoba R3T 2N2, Canada

${ }^{6}$ Institute for Big Data Analytics, Dalhousie University, 6299 South Street, Halifax, Nova Scotia B3H 4R2, Canada

${ }^{7}$ School of Earth and Ocean Sciences, University of Victoria, 3800 Finnerty Road, Victoria, British Columbia V8P 5C2, Canada

${ }^{8}$ JASCO Applied Sciences Ltd., 4464 Markham Street, Victoria, British Columbia V8Z 7X8, Canada

${ }^{9}$ Natural Resources Canada, 1 Challenger Drive, Dartmouth, Nova Scotia B2Y 4A2, Canada

${ }^{10}$ Department of Environment and Geography, University of Manitoba, 500 University Crescent, Winnipeg, Manitoba R3T 2N2, Canada

(C) The Arctic Institute of North America
} 


\section{INTRODUCTION}

Vessel traffic affects marine mammals in a variety of ways, including behavioural disturbance (Nowacek et al., 2007; Gomez et al., 2016), acoustic masking (Clark et al., 2009; Erbe et al., 2016), chemical contamination (i.e. oil spills) (Eide et al., 2007), and strikes (Vanderlaan and Taggart, 2009). Most of these effects are sub-lethal, but may cause significant impacts on fitness if the animal is exposed to vessels frequently (e.g., Ellison et al., 2016) or in combination with other stressors (National Academies of Sciences, Engineering, and Medicine, 2017). Behavioural disturbance and acoustic masking are likely the most pervasive forms of vessel impacts and are also very closely linked: animal vocalizations can only be masked when the animal can hear an acoustic signal from a noisy activity such as vessel noise, and hearing the acoustic signal from a vessel may elicit a behavioural response, especially in acoustically sensitive species. Behavioural disturbance for marine mammals can come in many forms, including avoidance (Richardson et al., 1985; LGL, 1986), changes to diving and respiration cycles (Richardson et al., 1990; Williams et al., 2014), cessation of foraging (Malme et al., 1988), and changes in vocalization characteristics (rates, frequency, source level) (Lesage et al., 1999; Scheifele et al., 2005; Holt et al., 2009; Blackwell et al., 2015, 2017). Disturbance can be biologically significant due to the combination of missed opportunities and energetic costs.

The Arctic has historically had less anthropogenic disturbance than non-polar regions (Moore et al., 2012; Reeves et al., 2014). However, climate change has been causing a reduction in summer sea ice (Stroeve et al., 2007; Markus et al., 2009), which has allowed for increased access to remote northern regions by vessel traffic (Pizzolato et al., 2014, 2016; Carter et al., 2018; Dawson et al., 2018). There have been relatively few studies on the impacts of vessel traffic on Arctic and sub-Arctic marine mammals, but the few studies that exist have found similar impacts (Terhune et al., 1979; Stewart et al., 1982; Richardson et al., 1985; LGL, 1986; Anderwald et al., 2013). A recent vulnerability analysis of Arctic marine mammals to vessel traffic along the Northwest Passage and Northern Sea Route also found that narwhal (Monodon monoceros Linnaeus, 1758), beluga whales (Delphinapterus leucas Pallas, 1776), bowhead whales (Balaena mysticetus Linnaeus, 1758), and walrus (Odobenus rosmarus Linnaeus, 1758) are most vulnerable to increased vessel traffic (Hauser et al., 2018).

In our study, we examined the influence of vessel traffic in the Mackenzie River estuary on the vocalizations of beluga whales. We used passive acoustic monitoring to detect beluga whale vocalizations over four years and then examined how the proximity of vessel traffic affected the quantity of beluga vocalizations. We tested the hypothesis that beluga whales change their behaviour in the presence of vessels and predicted that we would detect fewer beluga vocalizations when vessels were close to our acoustic recorders.

\section{METHODS}

\section{Study Area}

The Mackenzie River estuary is an important site for beluga whales from the Eastern Beaufort Sea population (Norton and Harwood, 1986). Belugas in this population migrate to the eastern Beaufort Sea and Amundsen Gulf during the summer, and thousands of belugas stop in the shallow waters of the Mackenzie River estuary (Bell et al., 2007; Harwood et al., 2014). This habitat is also protected by the Tarium Niryutait Marine Protected Area (TNMPA); the TNMPA management plan stipulates that vessels traveling through the TNMPA must follow community supply routes (Fisheries and Oceans Canada and Fisheries Joint Management Committee, 2013). Understanding how vessel traffic impacts beluga whales within this important habitat is critical information for the management of the TNMPA.

\section{Acoustic Data Collection}

We deployed acoustic recorders (models: SM2M and SM3M; Wildlife Acoustics, Maynard, Massachusetts, USA; hydrophones: HTI 96-MIN, High Tech Inc., Long Beach, Massachusetts, USA; hydrophone sensitivity: -164 to $-165 \mathrm{~dB}$ re $1 \mathrm{~V} / \mu \mathrm{Pa}$, flat response between $200 \mathrm{~Hz}$ and $10 \mathrm{kHz}$ ) in the shallow waters of Kugmallit Bay where the Mackenzie River flows into the Beaufort Sea in the western Canadian Arctic. Recorders were deployed between June and August each year in 2015-18, in up to five different sites throughout the bay (Fig. 1, Table 1), at water depths ranging from 1 to $8 \mathrm{~m}$ (Table 1), for a total of nine deployments of acoustic recorders throughout the study period. The mooring design consisted of a metal frame with four vertical posts, with the recorder supported vertically within the middle of the posts; the hydrophone was positioned $1 \mathrm{~m}$ off the bottom. One mooring in very shallow water (East Whitefish, Table 1) was set up with the acoustic recorder fixed on its side to a metal plate that was placed on the sea floor; the hydrophone on this mooring was positioned $0.3 \mathrm{~m}$ above the bottom. Recorders were set to either 96 or $384 \mathrm{kHz}$ sampling rates, with a duty cycle of 15 minutes recording every 30 minutes for recorders with the lower sampling rate, and 15 minutes recording every 60 minutes for the recorders with the higher sampling rate (Table 1). All recorders were set with $+16.5 \mathrm{~dB}$ of gain and a high pass filter at $180 \mathrm{~Hz}$; the high pass filter was set to reduce low frequency flow noise and because the shallow water would effectively stop all low frequency noise from propagating horizontally (Simard et al., 2014).

\section{Vessel Distance}

The distance between vessels and the acoustic recorders was estimated using satellite Automatic Identification System (AIS) data (Fig. 1), or from visual observations 


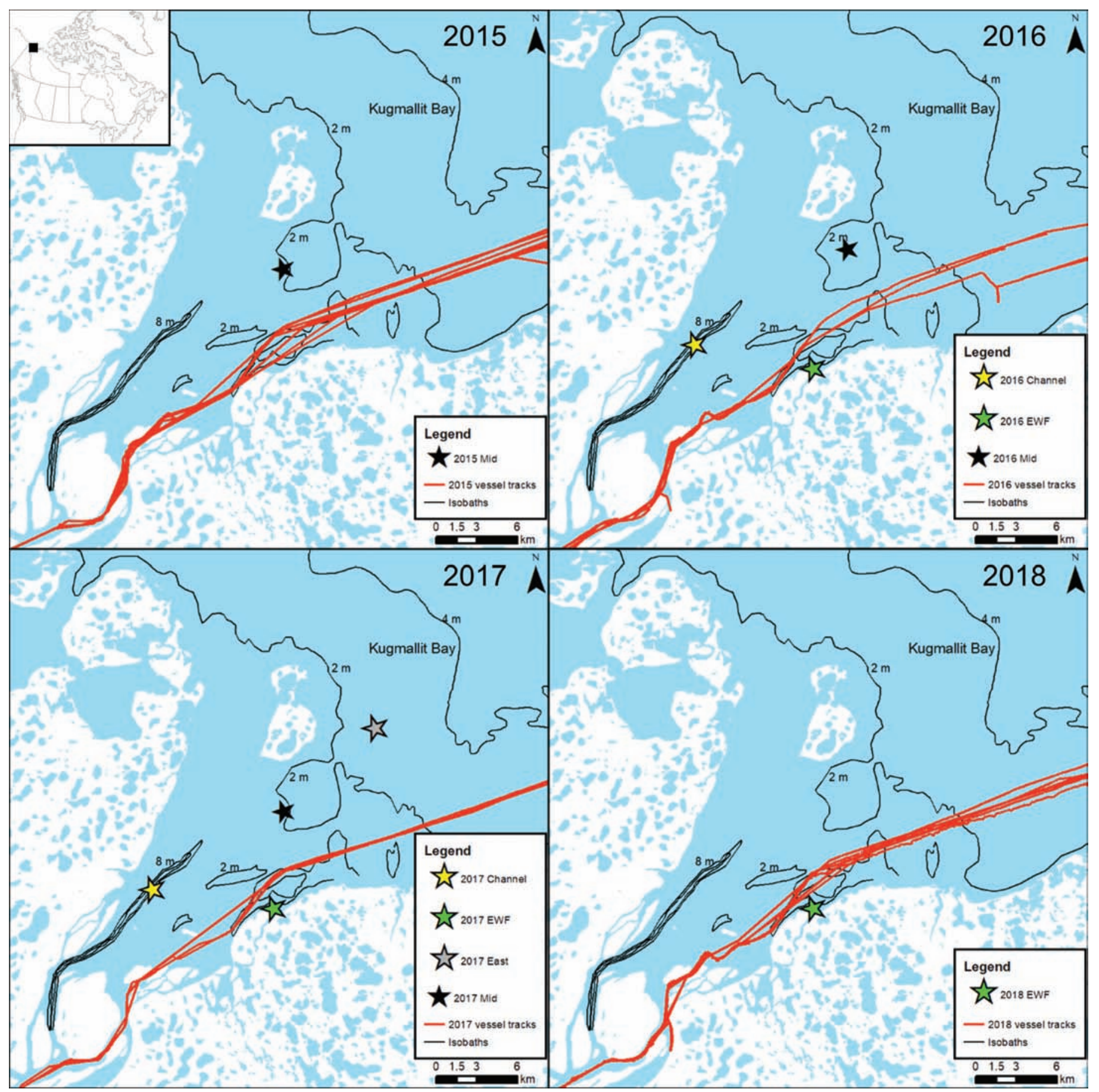

FIG. 1. Proximity of vessel tracks (derived from Automatic Identification System data) to acoustic recorders in the Mackenzie River estuary between 2015 and 2018. Stars represent the location and site name of acoustic recorders. Note that East Whitefish has been abbreviated to EWF.

on shore at the East Whitefish site for vessels without AIS transponders, either by field personnel $(n=1)$ or a shorebased automated camera $(n=7)$ (Table 1). For these visual observations, vessel distance was estimated based on the location of the community supply routes (Fig. 1) and average speeds of vessels traveling this route according to AIS data. We matched the distance between vessel tracks and each acoustic recorder throughout the deployment periods in each year of data collection. We then estimated the minimum and maximum distances between a vessel and the recorder in each 15-minute acoustic data file. We classified all files where a vessel was less than $10 \mathrm{~km}$ from the recorder an "impact" time segment. We then grouped time series of acoustic files together based on consecutive acoustic files when a vessel was within $10 \mathrm{~km}$ of the recorder and included an equivalent number of files both before and after the "impact" time segments. These files were then categorized as "before," "during," and "after." We also reclassified this series of files based on when a vessel was within $5 \mathrm{~km}$ of the acoustic recorder for the 
TABLE 1. Settings used for acoustic recorders that had overlap with vessel traffic within $10 \mathrm{~km}$, as well as the number of vessel series, and those with beluga whale vocalizations with vessels within $10 \mathrm{~km}$ and within $5 \mathrm{~km}$.

\begin{tabular}{|c|c|c|c|c|c|c|c|c|c|}
\hline Year & Location & $\begin{array}{c}\text { Deployment } \\
\text { days }\end{array}$ & $\begin{array}{l}\text { Sample rate } \\
(\mathrm{kHz})\end{array}$ & $\begin{array}{l}\text { Duty cycle } \\
\text { (min on/off) }\end{array}$ & Depth (m) & $\begin{array}{l}\text { Latitude, } \\
\text { Longitude }\end{array}$ & $\begin{array}{l}\text { \# Vessel series } \\
10 \mathrm{~km}\end{array}$ & $\begin{array}{c}\text { \# Vessel series } \\
10 \mathrm{~km} \\
\text { with belugas }\end{array}$ & $\begin{array}{c}\text { \# Vessel series } \\
5 \mathrm{~km} \\
\text { with belugas }\end{array}$ \\
\hline 2015 & Mid & 67 & 96 & $15 / 15$ & 1.6 & $69.4465^{\circ} \mathrm{N}, 133.6124^{\circ} \mathrm{W}$ & 9 & 4 & 3 \\
\hline \multirow[t]{3}{*}{2016} & Channel & 60 & 96 & $15 / 15$ & 8 & $69.3981^{\circ} \mathrm{N}, 133.8560^{\circ} \mathrm{W}$ & 3 & 0 & 0 \\
\hline & East Whitefish & 71 & 384 & $15 / 45$ & 1 & $69.3804^{\circ} \mathrm{N}, 133.6344^{\circ} \mathrm{W}$ & 4 & 0 & 0 \\
\hline & Mid & 60 & 96 & $15 / 15$ & 1.6 & $69.4591^{\circ} \mathrm{N}, 133.5650^{\circ} \mathrm{W}$ & 2 & 1 & 1 \\
\hline \multirow[t]{4}{*}{2017} & Channel & 61 & 96 & $15 / 15$ & 8 & $69.3947^{\circ} \mathrm{N}, 133.8620^{\circ} \mathrm{W}$ & 2 & 0 & 0 \\
\hline & East & 62 & 384 & $15 / 45$ & 1.6 & $69.4984^{\circ} \mathrm{N}, 133.4346^{\circ} \mathrm{W}$ & 3 & 3 & 0 \\
\hline & East Whitefish & 62 & 384 & $15 / 45$ & 1 & $69.3804^{\circ} \mathrm{N}, 133.6344^{\circ} \mathrm{W}$ & $11^{1}$ & $4^{2}$ & $4^{2}$ \\
\hline & Mid & 63 & 384 & $15 / 45$ & 1.6 & $69.4448^{\circ} \mathrm{N}, 133.6113^{\circ} \mathrm{W}$ & 2 & 0 & 0 \\
\hline 2018 & East Whitefish & 50 & 384 & $15 / 45$ & 1 & $69.3804^{\circ} \mathrm{N}, 133.6344^{\circ} \mathrm{W}$ & 9 & 3 & 3 \\
\hline Total & & & & & & & 45 & 15 & 11 \\
\hline
\end{tabular}

${ }^{1}$ Includes eight visual observations of vessels from shore.

${ }^{2}$ Includes three visual observations of vessels from shore. All other series are based on AIS (Automatic Identification System) data.

"during" segment. We also randomly selected an equal number of control time series where vessels were over $30 \mathrm{~km}$ away from the acoustic recorders in order to control for natural variation in beluga vocalizations in the absence of vessels. These two sets of series, the vessel series and the control series, allowed us to perform a pseudo before-after control-impact analysis (see Statistical Analyses below). For the control series, we selected six hours of data (the average length of the vessel series), and classified the first two hours as "before," the second two hours as "during," and the final two hours as "after." For these control series, we first confirmed that beluga vocalizations were present in the first file of the series, just as we did for the vessel series. We do not assume that the vocalizations in all files within a time series are from the same belugas, given that belugas are highly mobile. Instead, by comparing the control time series with the vessel time series, we are able to compare natural variation in beluga vocalizations with those exposed to vessels, regardless of whether the same belugas are being detected at the start and end of the time series.

\section{Beluga Vocalizations}

We used automated detectors and classifiers to estimate the number of pulsed calls (Fig. 2A) and whistles (Fig. 2B) within all files that were part of the times series of acoustic files identified in the previous section. The whistle detector uses a random forest classifier to detect acoustic signals and to classify them to marine mammal species in the western Arctic. The detector was trained based on marine mammal vocalizations collected in the northeastern Chukchi Sea (Hannay et al., 2013; Mouy et al., 2013). The details of this detector and classifier are fully described in Mouy et al. (2013), and this detector has been effectively used to classify beluga whale whistles in the western Canadian Arctic (Halliday et al., 2018a, 2019). The pulsed call detector was built in Raven Pro, version 1.5 (Bioacoustics Research Program, 2017) using the band limited energy detector with the spectrogram set to a window size of 7000 samples for files with a $96 \mathrm{kHz}$ sample rate and 10000 samples for files with a $384 \mathrm{kHz}$ sample rate, minimum frequency set to $16 \mathrm{kHz}$, maximum frequency at $48 \mathrm{kHz}$, minimum duration at $0.1 \mathrm{~s}$, maximum duration at $2.5 \mathrm{~s}$, minimum separation at $0.05 \mathrm{~s}$, signal-tonoise ratio threshold at $2 \mathrm{~dB}$, block size at $10 \mathrm{~s}$, and hop size at $5 \mathrm{~s}$.

We visually and aurally scanned through all files in each series in Raven to assess the efficacy of the detectors. In a small subset, we manually counted all pulsed calls and whistles and compared these to the counts from the automated detectors and classifiers. In every file, we assessed the presence of pulsed calls and whistles and also looked for broadband noise from waves or other broadband signals that confused the pulsed call detector (Fig. 2C). If other broadband noise was present and triggered the detectors, we corrected the automated call counts from the detectors by removing false positives. We did not adjust for false negatives.

We calculated the mean broadband sound pressure level (SPL) between $200 \mathrm{~Hz}$ and $48 \mathrm{kHz}$ in each file selected for this analysis using the PAMGuide package (Merchant et al., 2015) in Matlab (version 2017a; MathWorks, Natick, Massachusetts, USA).

\section{Statistical Analyses}

We analyzed the impact of the distance of vessels on beluga vocalizations in the range of the acoustic recorder using a before-after control-impact design. We only included time series that had beluga vocalizations in the "before" time segments because the purpose of this analysis was to assess the impact of vessels on vocalizations. We used linear mixed effects models in R (package: lme4; function: Imer; Bates et al., 2015; R Core Team, 2016) with the total number of vocalizations within a file (sum of pulsed calls and whistles) as the dependent variable, and the distance of the vessel to the recorder (either categorical with the "during" segment set as distance within $10 \mathrm{~km}$ or $5 \mathrm{~km}$, 

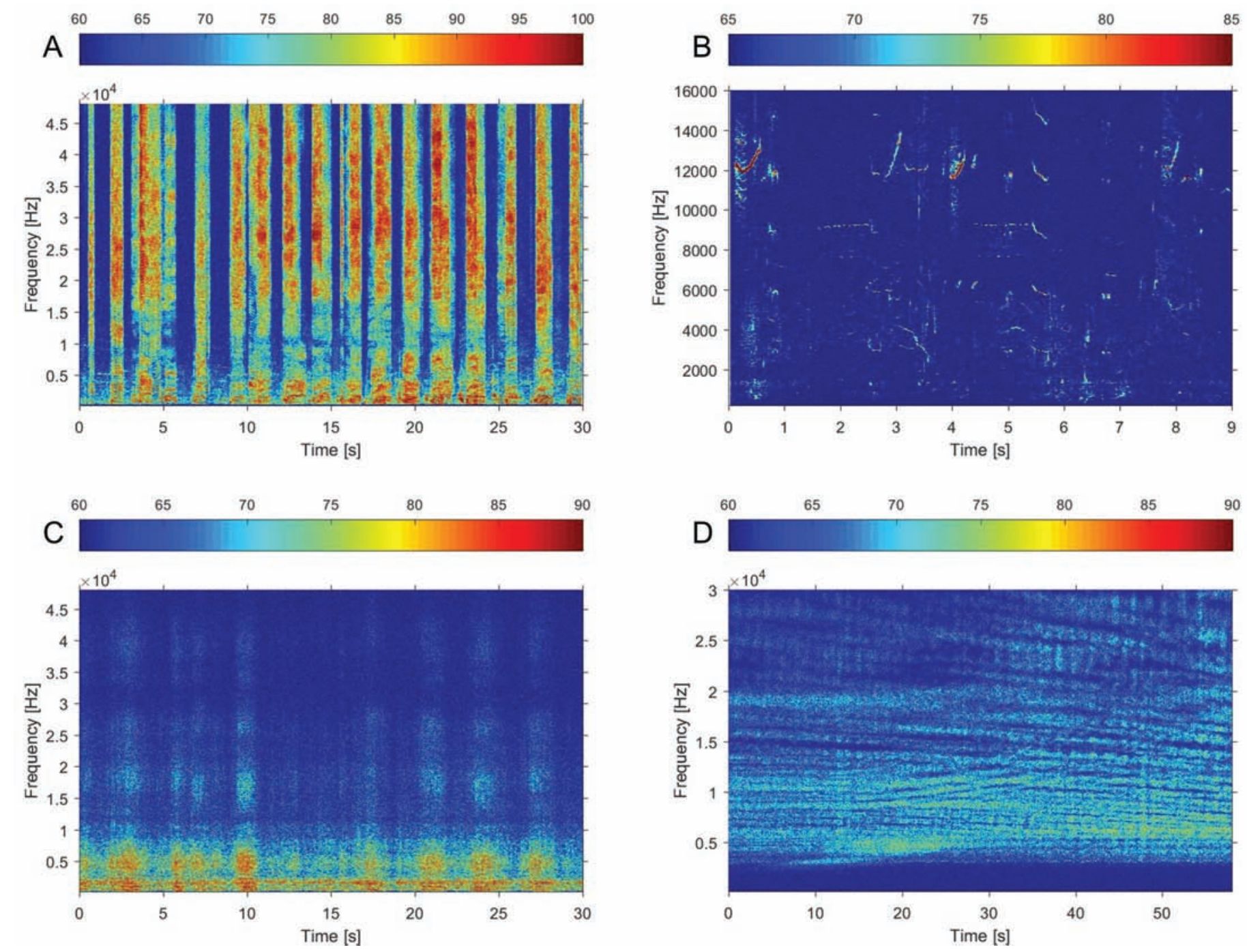

FIG. 2. Example spectrograms of beluga whale pulsed calls (A), beluga whistles (B), and noise from waves that can cause false positives for the pulsed call detector (C). Figure 2D shows one of the few examples of vessel noise in the data. Window size in all spectrograms was set to 12000 samples. The colour bars show the range and colours associated with different power spectral densities ( $\mathrm{dB}$ re $1 \mu \mathrm{Pa} 2 / \mathrm{Hz}$ ) in each panel.

or continuous) as a fixed effect. We included a categorical variable that identifies the time series as control (vessel absent) or impact (vessel present), and the interaction between the vessel distance variable and the control-impact variable as fixed effects. We also included broadband SPL $(200 \mathrm{~Hz}$ to $48 \mathrm{kHz})$ as a covariate to control for any masking effects of ambient sound levels or vessel noise. We included the time series, order of files, and location of the recorder as random effects. We compared models with the three different variables for distance (continuous variable for distance, or categorical variable with "during" set to $10 \mathrm{~km}$ or $5 \mathrm{~km}$ ) using Akaike's information criterion (AICc) corrected for small sample sizes (package: qpcR; function: AICc; Spiess, 2014). The sample size for the impact series when the "during" level was set to within $10 \mathrm{~km}$ was 15 time series, but this was reduced to 11 time series when the "during" level was set to within $5 \mathrm{~km}$ (Table 1). We therefore only compared AICc for models with this smaller sample size, because AICc can only be compared between models with the same sample size (Burnham and Anderson, 2002). Any models within 2 AICc units of each other were considered to be competing (Burnham and Anderson, 2002). We also assessed models that used the number of whistles and the number of pulsed calls separately as the dependent variables.

While we did include SPL as a covariate in this analysis, there was no significant noise from vessels in this dataset, which we demonstrate by regressing broadband SPL by the distance between the vessel and the acoustic recorder (package: stats; function: 1m; R Core Team, 2016). Only 11 of the 159 files where vessels were within $10 \mathrm{~km}$ of the acoustic recorder actually contained evidence of vessel noise. This vessel noise is demonstrated by the tonals (long signals at constant frequencies) and broadband signals shown in Fig. 2D), and of these, the closest was $1.2 \mathrm{~km}$ from the recorder. In our final sample with beluga vocalizations, only six files had evidence of vessel noise. There are two main reasons that we did not detect much vessel noise. 


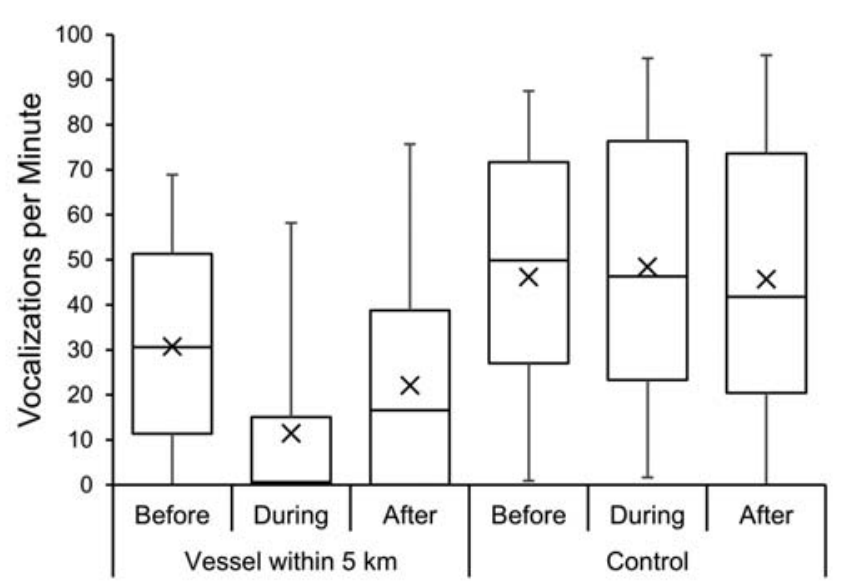

FIG. 3. Number of beluga vocalizations (sum of whistles and pulsed calls) per minute in time segments before, during, and after when a vessel was within $5 \mathrm{~km}$ of the acoustic recorder, as well as during random control periods when no vessels were nearby. Boxes represent the interquartile range, the line within the boxes is the median, whiskers are the minima and maxima, and $\times$ is the mean value.

First, the water was extremely shallow, which did not allow vessel noise to propagate very far. Second, the recorders were set with a high pass filter at $180 \mathrm{~Hz}$, which cut off any low frequency vessel noise that would have reached the recorders. In the few cases where vessel noise was detected, it covered relatively high frequencies and was rarely detected below $4 \mathrm{kHz}$ (Fig. 2D), which is entirely due to propagation effects rather than the high pass filter.

\section{RESULTS}

The number of beluga whale vocalizations received at the recorder decreased when vessels were closest to the acoustic recorders in the impact time series $\left(t_{173}=2.27\right.$, $p=0.02)$, but remained relatively constant through time in the control time series ( $p>0.36$; Fig. 3). Vocalization levels were not significantly different overall between the control and impact time series $\left(t_{25}=1.81, p=0.08\right)$. The model that used a categorical distance variable with the "during" segment set to $5 \mathrm{~km}$ was the strongest model, although the model with "during" set to $10 \mathrm{~km}$ was almost as strong $(\triangle \mathrm{AICc}=2.0)$; the model with distance as a continuous variable was the weakest model $(\triangle \mathrm{AICc}=39.1)$, which suggests that the relationship is not linear. For the model with the "during" segment set to $5 \mathrm{~km}$, within the impact time series, the "during" segment had $12 \pm 5$ fewer vocalizations per minute than the "before" segment $\left(t_{173}=2.27, p=0.02\right)$, and the "after" segment was not significantly different than either the "before" segment $\left(t_{173}=1.07, p=0.29\right.$ ) (Fig. 3) or the "during" segment $(p=0.18)$ (i.e., the "after" segment was intermediate and overlapping with both the "before" and "during" segments). The model with "during" set to $10 \mathrm{~km}$ had the same trend as the model with "during" set to $5 \mathrm{~km}$, with more vocalizations before the encounter than during the

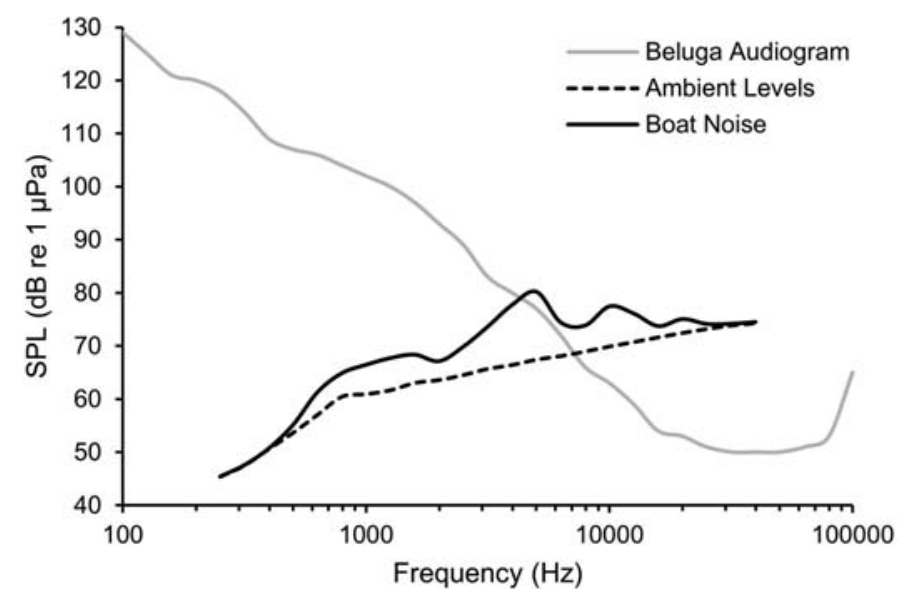

FIG. 4. The audiogram for beluga whales (Castellote et al., 2014; Erbe et al., 2016; Mooney et al., 2018) (grey solid line) versus received noise from a tugboat (black solid line), and ambient sound levels in the absence of vessel noise and beluga vocalizations (black dashed line). Both spectra for tugboat noise and ambient sound levels were from the recorders and sites used in this study. The tugboat was just over $1 \mathrm{~km}$ from the recorder under calm, quiet conditions. Sound pressure level (SPL) is measured in 1/3-octave bands.

encounter. Models that examined the total number of whistles or pulsed calls had qualitatively similar results to the model examining all vocalizations combined, with fewer vocalizations in the "during" segment than in the "before" segment. The number of vocalizations increased as SPL increased (slope $=1.44 \pm 0.19$ vocalizations $/ \mathrm{dB}$; $\left.t_{194}=7.48, p<0.0001\right)$, and SPL was unaffected by the distance to the nearest vessel $\left(t_{109}=0.49, p=0.63\right)$.

\section{DISCUSSION}

We provide evidence that beluga whales showed behavioural responses to vessels in the shallow Mackenzie River estuary based on a decrease in vocalizations in the range of our acoustic recorders. The few previous studies examining the impact of vessel traffic on Arctic beluga whales have found that belugas can be quite sensitive to icebreaking vessels, showing avoidance behaviour when the icebreaker is nearly $50 \mathrm{~km}$ away (LGL, 1986) and showing avoidance behaviour and cessation of foraging in response to other vessels (Stewart et al., 1982). Non-Arctic beluga whales in the St. Lawrence River estuary have also been shown to change their vocalizations in response to vessel noise (Lesage et al., 1999; Scheifele et al., 2005). In our study area we are unable to determine whether belugas simply stop vocalizing in response to vessel traffic or if they are avoiding the vessels and moving away from the acoustic recorders, thereby reducing our ability to record their vocalizations. The possibility also exists that the whales approached the vessels, either silently or out of our vocal detection range. However, during one of our visual observations, the observers saw $12-15$ belugas before a vessel approached, and as the vessel approached, the whales were no longer observed in the area (K. Scharffenberg, pers. obser. 2017), likely showing avoidance behaviour in 
response to the vessel. Community members have observed belugas avoiding barges and other vessels in this system for many years (H. Lennie, pers. comm. 2019). However, we cannot say whether this occurred in all examples where vocalizations decreased when a vessel was close since we were relying on acoustic data without visual observations of belugas. Future work should pair visual observations with acoustic recordings in order to fully understand how belugas react to vessels in this shallow water environment.

Although we were unable to assess the impact of underwater noise from vessels on beluga vocalizations, it is very likely that distance to the vessel was highly correlated with vessel noise for receivers closer to the vessels. In the few files where we detected vessel noise, that noise should have been audible to belugas based on the beluga audiogram (Fig. 4) (Castellote et al., 2014; Erbe et al., 2016; Mooney et al., 2018). However, given that we were unable to detect noise from vessels in most time series and were also not able to determine where belugas were located relative to the vessel, we cannot determine whether belugas were reacting to vessel noise or simply to the presence of the vessel. The beluga vocalizations that we detected were likely from belugas within a $2 \mathrm{~km}$ radius around the acoustic recorders: beluga vocalizations below $10 \mathrm{kHz}$ may be detected at ranges up to $2 \mathrm{~km}$ and high frequency vocalizations at ranges up to $1 \mathrm{~km}$, based on source level of $120 \mathrm{~dB}$ re $1 \mu \mathrm{Pa}$ at $1 \mathrm{~m}$, background noise level at that frequency of $50 \mathrm{~dB}$ re $1 \mu \mathrm{Pa}$, a simple spherical transmission loss calculation accounting for frequency-dependent attenuation (see equation 4.20 in $\mathrm{Au}$ and Hastings, 2008), and assuming that the shallow bathymetry of this system would reduce the range. However, modelling and playback experiments would be required to precisely estimate these ranges. This remains an open question and is worthy of further investigation. Given the high sensitivity of belugas to underwater noise and disturbance from vessels (LGL, 1986), it is possible that the acoustic cue that the belugas were responding to was low amplitude and may have been difficult for us to detect.

The trends that we present in this study are not driven by masking effects. Detectability of vocalizations may often be influenced by ambient sound levels (Serrano and Terhune, 2002) or underwater noise from vessels (Vasconcelos et al., 2007). However, in this study, the proximity of vessels did not influence SPL, and SPL was positively correlated with the number of beluga vocalizations. We previously demonstrated that beluga vocalizations control much of the high frequency energy in this shallow water soundscape and are even detectable above the sounds created by wind and waves (Halliday et al., unpubl. data). The results that we present here confirm this trend and also provide evidence that beluga vocalizations are not being masked by ambient sounds or by vessel noise. We are therefore confident that in the proximity of vessels, beluga vocalizations in the range of the acoustic recorder are decreasing, rather than being masked by vessel noise.

\section{Management Recommendations}

The most effective way to reduce the impacts of vessels on belugas would be to exclude vessels from important beluga areas (Halliday et al., 2018b; McWhinnie et al., 2018). However, this option would be difficult to enact in the TNMPA. Vessels traveling within the TNMPA are required to follow the community supply route in order to minimize their impacts within the TNMPA (Fisheries and Oceans Canada and Fisheries Joint Management Committee, 2013), but the community supply route is also one of the only navigable waterways between Inuvik and Tuktoyaktuk, so vessels may not be able to deviate significantly from this route. Beluga hotspots, identified by aerial surveys, have a strong spatial overlap with the community supply route (Harwood et al., 2014). Since the supply route likely cannot move to avoid beluga hotspots, managers likely cannot fully exclude vessels from this area. Another option is to use an adaptive strategy that only excludes vessels when belugas are present. However, belugas are generally present for the entire month of July (Harwood et al., 2014) and are also detected into late August (Scharffenberg et al., 2019; Halliday et al., unpubl. data). This type of seasonal exclusion would mean that vessels could only travel the route starting in late August, which would drastically reduce the shipping season for these vessels. Reducing vessel speed is another popular management option in other systems, but are likely not viable in this system because vessels are already travelling slowly. For example, in 2017, vessels travelled a minimum of 2.7 knots $(5.0 \mathrm{~km} / \mathrm{h})$, a maximum of $8.4 \mathrm{knots}(15.6 \mathrm{~km} / \mathrm{h})$, and a mean of 5.6 knots $(10.4 \mathrm{~km} / \mathrm{h})$ along this route. One final option is for vessels to carry marine mammal observers and to slow or stop completely when they encounter belugas. This will not account for the $5 \mathrm{~km}$ radius of impact that we identified in this study, but for belugas that travel closer to vessels, such as in narrow channels, this could reduce the auditory masking and stress response for those belugas.

There are multiple factors that must also be taken into consideration when assessing management strategies. First of all, the TNMPA was put in place to support the harvest of belugas by Inuvialuit hunters. Disturbance by vessels could cause belugas to flee from these hunting grounds, which would reduce the success of the hunters. The long-term consequences of disturbance by vessels on belugas is also not understood and must be researched before the impact of vessels can be fully assessed. Continued monitoring of both belugas and vessels is required in order to track changes into the future; importantly, earlier ice melt may lead to earlier vessel transits and likewise could impact the timing of belugas' use of the same waters. Tracking these changes is critical to the future management and conservation of this stock of belugas. 


\section{ACKNOWLEDGEMENTS}

Funding, support, and partnerships for this project were provided by Fisheries and Oceans Canada, the Fisheries Joint Management Committee, the Inuvik and Tuktoyaktuk Hunters and Trappers Committees, the Aurora Research Institute, Natural Resources Canada (including the Polar Continental Shelf Program), the Northern Scientific Training Program, and the W. Garfield Weston Foundation. This project would not have been possible without the support of our field crew that included: E. Way-Nee, J. Pascal, D. Swainson, C. Hoover, K. Tingmiak, A. Gordon Jr., J. Pokiak, A. Robertson, P. Lennie, and our camp hosts, C. Day, B. Joe, and F. Angasuk. Satellite AIS data were provided by exactEarth Ltd. (2019), and processed courtesy of MEOPAR National Centre for Excellence.

\section{REFERENCES}

Anderwald, P., Brandecker, A., Coleman, M., Collins, C., Denniston, H., Haberlin, M.D., O’Donovan, M., Pinfield, R., Visser, F., and Walshe, L. 2013. Displacement responses of a mysticete, an odontocete, and a phocid seal to constructionrelated vessel traffic. Endangered Species Research 21(3):231 - 240.

https://doi.org/10.3354/esr00523

$\mathrm{Au}$, W.W.L., and Hastings, M.C. 2008. Principles of marine bioacoustics. New York: Springer Science+Business Media, LLC.

Bates, D., Mächler, M., Bolker, B., and Walker, S. 2015. Fitting linear mixed-effects models using lme4. Journal of Statistical Software 67(1). 48 p. https://doi.org/10.18637/jss.v067.i01

Bell, S.L.M., Herman, T.B., and Wassersug, R.J. 2007. Ecology of Thamnophis sauritus (eastern ribbon snake) at the northern limit of its range. Northeastern Naturalist 14(2):279-292. https://doi.org/10.1656/1092-6194(2007)14[279:EOTSER]2.0. $\mathrm{CO} ; 2$

Bioacoustics Research Program. 2017. Raven Pro: Interactive sound analysis software (Version 1.5). Ithaca, New York: The Cornell Lab of Ornithology.

http://www.birds.cornell.edu/raven

Blackwell, S.B., Nations, C.S., McDonald, T.L., Thode, A.M., Mathias, D., Kim, K.H., Greene, C.R., Jr., and Macrander, A.M. 2015. Effects of airgun sounds on bowhead whale calling rates: Evidence for two behavioral thresholds. PLoS ONE 10: e0125720. https://doi.org/10.1371/journal.pone.0125720

Blackwell, S.B., Nations, C.S., Thode, A.M., Kauffman, M.E., Conrad, A.S., Norman, R.G., and Kim, K.H. 2017. Effects of tones associated with drilling activities on bowhead whale calling rates. PLoS ONE 12: e0188459. https://doi.org/10.1371/journal.pone.0188459

Burnham, K.P., and Anderson, D.R. 2002. Model selection and multimodel inference: A practical information-theoretic approach, 2nd ed. Berlin: Springer.
Carter, N.A., Dawson, J., Parker, C., Cary, J., Gordon, H., Kochanowicz, Z., and Weber, M. 2018. Arctic corridors and northern voices: Governing marine transportation in the Canadian Arctic (Aklavik, Northwest Territories community report). Ottawa: University of Ottawa.

https://doi.org/10.20381/RUOR37326

Castellote, M., Mooney, T.A., Quakenbush, L., Hobbs, R., Goertz, C., and Gaglione, E. 2014. Baseline hearing abilities and variability in wild beluga whales (Delphinapterus leucas). Journal of Experimental Biology 217:1682-1691. https://doi.org/10.1242/jeb.093252

Clark, C.W., Ellison, W.T., Southall, B.L., Hatch, L., Van Parijs, S.M., Frankel, A., and Ponirakis, D. 2009. Acoustic masking in marine ecosystems: Intuitions, analysis, and implication. Marine Ecology Progress Series 395:201-222.

https://doi.org/10.3354/meps08402

Dawson, J., Pizzolato, L., Howell, S.E.L., Copland, L., and Johnston, M.E. 2018. Temporal and spatial patterns of ship traffic in the Canadian Arctic from 1990 to 2015. Arctic 71(1):15-26.

https://doi.org/10.14430/arctic4698

Eide, M.S., Endresen, Ø., Breivik, Ø., Willy, O., Brude, O.W., Ellingsen, I.H., Røang, K., Hauge, J., and Olaf, P.O. 2007. Prevention of oil spill from shipping by modelling of dynamic risk. Marine Pollution Bulletin 54(10):1619-1633.

https://doi.org/10.1016/j.marpolbul.2007.06.013

Ellison, W.T., Racca, R., Clark, C.W., Streever, B., Frankel, A.S., Fleishman, E., Angliss, R., et al. 2016. Modeling the aggregated exposure and responses of bowhead whales Balaena mysticetus to multiple sources of anthropogenic underwater sound. Endangered Species Research 30:95-108.

https://doi.org/10.3354/esr00727

Erbe, C., Reichmuth, C., Cunningham, K., Lucke, K., and Dooling, R. 2016. Communication masking in marine mammals: A review and research strategy. Marine Pollution Bulletin 103 (1-2):15-38.

https://doi.org/10.1016/j.marpolbul.2015.12.007

Fisheries and Oceans Canada and Fisheries Joint Management Committee. 2013. Tarium Niryutait marine protected areas management plan.

http:/www.beaufortseapartnership.ca/wp-content/uploads/ 2015/05/tnmpa-mgmt-plan_final.pdf

Gomez, C., Lawson, J.W., Wright, A.J., Buren, A.D., Tollit, D., and Lesage, V. 2016. A systematic review on the behavioural responses of wild marine mammals to noise: The disparity between science and policy. Canadian Journal of Zoology 94(12):801-819.

https://doi.org/10.1139/cjz-2016-0098

Halliday, W.D., Insley, S.J., de Jong, T., and Mouy, X. 2018a. Seasonal patterns in acoustic detections of marine mammals near Sachs Harbour, Northwest Territories. Arctic Science 4(3):259-278.

https://doi.org/10.1139/AS-2017-0021 
Halliday, W.D., Têtu, P.-L., Dawson, J., Insley, S.J., and Hilliard, R.C. 2018b. Tourist vessel traffic in important whale areas in the western Canadian Arctic: Risks and possible management solutions. Marine Policy 97:72-81. https://doi.org/10.1016/j.marpol.2018.08.035

Halliday, W.D., Pine, M.K., Insley, S.J., Soares, R.N., Kortsalo, P., and Mouy, X. 2019. Acoustic detections of Arctic marine mammals near Ulukhaktok, Northwest Territories, Canada. Canadian Journal of Zoology 97(1):72-80. https://doi.org/10.1139/cjz-2018-0077

Hannay, D.E., Delarue, J., Mouy, X., Martin, B.S., Leary, D., Oswald, J.N., and Vallarta, J. 2013. Marine mammal acoustic detections in the northeastern Chukchi Sea, September 2007-July 2011. Continental Shelf Research 67:127-146. https://doi.org/10.1016/j.csr.2013.07.009

Harwood, L.A., Iacozza, J., Auld, J.C., Norton, P., and Loseto, L. 2014. Belugas in the Mackenzie River estuary, NT, Canada: Habitat use and hot spots in the Tarium Niryutait Marine Protected Area. Ocean \& Coastal Management 100:128-138. https://doi.org/10.1016/j.ocecoaman.2014.08.004

Hauser, D.D.W., Laidre, K.L., and Stern, H.L. 2018. Vulnerability of Arctic marine mammals to vessel traffic in the increasingly icefree Northwest Passage and Northern Sea Route. Proceedings of the National Academy of Sciences 115(29):7617-7622. https://doi.org/10.1073/pnas.1803543115

Holt, M.M., Noren, D.P., Veirs, V., Emmons, C.K., and Veirs, S. 2009. Speaking up: Killer whales (Orcinus orca) increase their call amplitude in response to vessel noise. Journal of the Acoustical Society of America 125(1):EL27-32. https://doi.org/10.1121/1.3040028

Lesage, V., Barrette, C., Kingsley, M.C.S., and Sjare, B. 1999. The effect of vessel noise on the vocal behavior of belugas in the St. Lawrence River estuary, Canada. Marine Mammal Science 15(1):65-84. https://doi.org/10.1111/j.1748-7692.1999.tb00782.x

LGL. 1986. Reactions of beluga whales and narwhals to ship traffic and ice-breaking along ice edges in the eastern Canadian High Arctic 1982-1984. Environmental Studies No. 37. Ottawa: Indian and Northern Affairs Canada.

Malme, C.I., Würsig, B., Bird, J.E., and Tyack, P. 1988. Observations of feeding gray whale responses to controlled industrial noise exposure. In: Sackinger, W.M., Jeffries, M.O., Imm, J.L., and Treacy, S.D., eds. Port and ocean engineering under Arctic conditions, Vol. II Symposium on noise and marine mammals. Fairbanks: Geophysical Institute, University of Alaska Fairbanks. 55-73.

Markus, T., Stroeve, J.C., and Miller, J. 2009. Recent changes in Arctic sea ice melt onset, freezeup, and melt season length. Journal of Geophysical Research 114, C12024. https://doi.org/10.1029/2009JC005436

McWhinnie, L.H., Halliday, W.D., Insley, S.J., Hilliard, C., and Canessa, R.R. 2018. Vessel traffic in the Canadian Arctic: Management solutions for minimizing impacts on whales in a changing northern region. Ocean \& Coastal Management 160:1-17. https://doi.org/10.1016/j.ocecoaman.2018.03.042
Merchant, N.D., Fristrup, K.M., Johnson, M.P., Tyack, P.L., Witt, M.J., Blondel, P., and Parks, S.E. 2015. Measuring acoustic habitats. Methods in Ecology and Evolution 6(3):257-265. https://doi.org/10.1111/2041-210X.12330

Mooney, T.A., Castellote, M., Quakenbush, L., Hobbs, R., Gaglione, E., and Goertz, C. 2018. Variation in hearing within a wild population of beluga whales (Delphinapterus leucas). Journal of Experimental Biology 221: jeb171959. https://doi.org/10.1242/jeb.171959

Moore, S.E., Reeves, R.R., Southall, B.L., Ragen, T.J., Suydam, R.S., and Clark, C.W. 2012. A new framework for assessing the effects of anthropogenic sound on marine mammals in a rapidly changing Arctic. BioScience 62(3):289-295.

https://doi.org/10.1525/bio.2012.62.3.10

Mouy, X., Oswald, J.N., Leary, D., Delarue, J., Vallarta, J., Rideout, B., Mellinger, D., Erbe, C., Hannay, D., and Martin, B. 2013. Passive acoustic monitoring of marine mammals in the Arctic. In: Adam, O., and Samaran, F., eds. Detection, classification, localization of marine mammals using passive acoustics. Paris, France: Dirac NGO. 185-224.

National Academies of Sciences, Engineering, and Medicine. 2017. Approaches to understanding the cumulative effects of stressors on marine mammals. Washington, DC: The National Academies Press. https://doi.org/10.17226/23479

Norton, P., and Harwood, L.A. 1986. Distribution, abundance and behaviour of white whales in the Mackenzie Estuary. Environmental Studies Revolving Funds, Report No. 036. Ottawa. 73 p.

Nowacek, D.P., Thorne, L.H., Johnston, D.W., and Tyack, P.L. 2007. Responses of cetaceans to anthropogenic noise. Mammal Review 37(2):81-115. https://doi.org/10.1111/j.1365-2907.2007.00104.x

Pizzolato, L., Howell, S.E.L., Derksen, C., Dawson, J., and Copland, L. 2014. Changing sea ice conditions and marine transportation activity in Canadian Arctic waters between 1990 and 2012. Climatic Change 123(2):161 - 173. https://doi.org/10.1007/s10584-013-1038-3

Pizzolato, L., Howell, S.E.L., Dawson, J., Laliberté, F., and Copland, L. 2016. The influence of declining sea ice on shipping activity in the Canadian Arctic. Geophysical Research Letters 43(23):12146- 12154. https://doi.org/10.1002/2016GL071489

R Core Team. 2016. R: A language and environment for statistical computing. Version 3.3.0. Vienna, Austria: R Foundation for Statistical Computing.

www.r-project.org

Reeves, R.R., Ewins, P.J., Agbayani, S., Heide-Jørgensen, M.P., Kovacs, K.M., Lydersen, C., Suydam, R., et al. 2014. Distribution of endemic cetaceans in relation to hydrocarbon development and commercial shipping in a warming Arctic. Marine Policy 44:375-389. https://doi.org/10.1016/j.marpol.2013.10.005 
Richardson, W.J., Fraker, M.A., Würsig, B., and Wells, R.S. 1985. Behaviour of bowhead whales Balaena mysticetus summering in the Beaufort Sea: Reactions to industrial activities. Biological Conservation 32(3):195-230. https://doi.org/10.1016/0006-3207(85)90111-9

Richardson, W.J., Würsig, B., and Greene, C.R., Jr. 1990. Reactions of bowhead whales, Balaena mysticetus, to drilling and dredging noise in the Canadian Beaufort Sea. Marine Environmental Research 29(2):135-160. https://doi.org/10.1016/0141-1136(90)90032-J

Scharffenberg, K., Whalen, D., Marcoux, M., Iacozza, J., Davoren, G., and Loseto, L. 2019. Environmental drivers of beluga whale Delphinapterus leucas habitat use in the Mackenzie Estuary, Northwest Territories, Canada. Marine Ecology Progress Series 626:209-226. https://doi.org/10.3354/meps13011

Scheifele, P.M., Andrew, S., Cooper, R.A., Darre, M., Musiek, F.E., and Max, L. 2005. Indication of a Lombard vocal response in the St. Lawrence River beluga. Journal of the Acoustical Society of America 117(3):1486-1492. https://doi.org/10.1121/1.1835508

Serrano, A., and Terhune, J.M. 2002. Antimasking aspects of harp seal (Pagophilus groenlandicus) underwater vocalizations. Journal of the Acoustical Society of America 112(6):3083-3090. https://doi.org/10.1121/1.1518987

Simard, Y., Loseto, L., Gautier, S., and Roy, N. 2014. Monitoring beluga habitat use and underwater noise levels in the Mackenzie Estuary: Application of passive acoustics in summers 2011 and 2012. Canadian Technical Report of Fisheries and Aquatic Sciences 3068. vi +49 p.

Spiess, A.-N. 2014. qpcR: Modelling and analysis of real-time PCR data. Vienna, Austria: R Foundation for Statistical Computing. https://rdrr.io/cran/qpcR/
Stewart, B.S., Evans, W.E., and Awbrey, F.T. 1982. Effects of man-made waterborne noise on behavior of beluga whales (Delphinapterus leucas) in Bristol Bay, Alaska. HSWRI Technical Report 82-145. Report from Hubbs/Sea World Research Institute, San Diego, California for the U.S. National Oceanic and Atmospheric Administration. Juneau, Alaska. 29 p.

Stroeve, J., Holland, M.M., Meier, W., Scambos, T., and Serreze, M. 2007. Arctic sea ice decline: Faster than forecast. Geophysical Research Letters 34(9), L09501. https://doi.org/10.1029/2007GL029703

Terhune, J.M., Stewart, R.E.A., and Ronald, K. 1979. Influence of vessel noises on underwater vocal activity of harp seals. Canadian Journal of Zoology 57(6):1337-1338. https://doi.org/10.1139/z79-170

Vanderlaan, A.S.M., and Taggart, C.T. 2009. Efficacy of a voluntary area to be avoided to reduce risk of lethal vessel strikes to endangered whales. Conservation Biology 23(6):1467-1474. https://doi.org/10.1111/j.1523-1739.2009.01329.x

Vasconcelos, R.O., Amorim, M.C.P., and Ladich, F. 2007. Effects of ship noise on the detectability of communication signals in the Lusitanian toadfish. Journal of Experimental Biology 210(12):2104-2112. https://doi.org/10.1242/jeb.004317

Williams, R., Erbe, C., Ashe, E., Beerman, A., and Smith, J. 2014. Severity of killer whale behavioral responses to ship noise: A dose-response study. Marine Pollution Bulletin 79 (1-2):254-260.

https://doi.org/10.1016/j.marpolbul.2013.12.004 